\title{
Religious statecraft: Zionism and Constantinianism in Ethiopian religious-martial policy
}

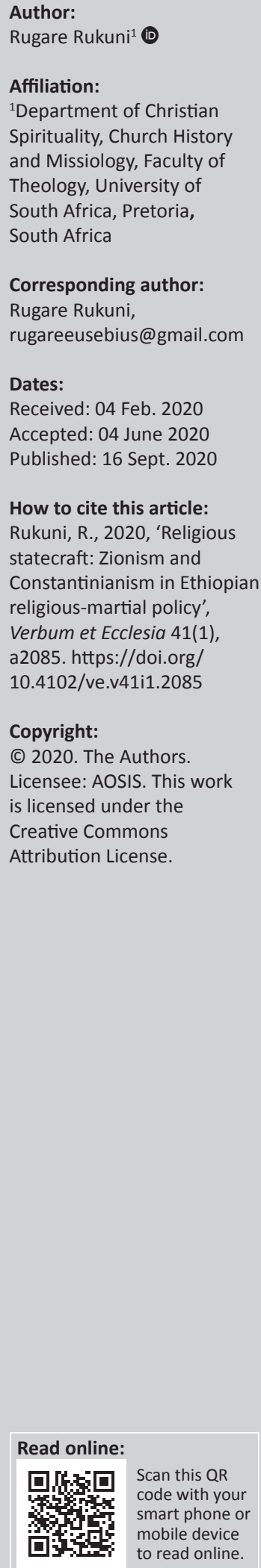

Ethiopia as a theme is replete in the Hadith and Pseudo-Methodius, ironically perspectives from the two sides of the same war. Dually, Ethiopia was an Islamic friend and later a foe. In its response to Islamification, Ethiopia embellished its mythical-legendary heroic status in Eastern Christianity. This implies an existent religious-martial policy, which can be viewed against the reality of the religious-political complex that shaped Ethiopia. This research has been accomplished using document analysis. The parallel study of Ethiopia's interaction with Islam, Judaic-Zionism and Constantinian dynamics concocts the reality of religious statecraft. Attaching the perceived religious statecraft of Ethiopia to the nation's overall narrative established the notion of a religious-martial policy. The preceding corroborates a theory of religious statecraft as derived from the narratives of Ethiopian Christian history.

Intradisciplinary and/or interdisciplinary implications: Whilst the study is mainly a church history review of historical Ethiopia's war encounters and their religious perspectives, there is an element of late antiquity as per the reference to imperial Constantinian religiously motivated wars. In addition, there is a component of political philosophy as embellished in the discussion on Zionism. By extension, there is an element of Islamic studies consequent to the review of the dynamics within Ethiopia's region during late antiquity. Dually, a semblance of biblical studies is reflected in a review of the Ethiopic Solomonic Dynasty theology, which is a derivative of the Old Testament, and in a review of pseudo-epigraphical literature.

Keywords: Christian history; Constantinianism; religious statecraft; Ethiopia; Zionism; Islam.

\section{Introduction: Antique theocracy: The basis for religious-martial policy}

The narrative of the Judaic-Christian nation of Ethiopia is punctuated within the connotations of religious conflict (Rukuni \& Oliver 2019a, 2019b, 2019c; Rukuni 2020). From the perspective of its complex religious-cultural-political complex, a definitive approach regarding Ethiopia's religious-military pursuits would be enlightening. Therefore, this research will establish links between Ethiopian religious-martial policy and the different systems of religious statecraft. Correspondingly, it will explore how the essential nature of the Ethiopian church-state substantiated the response to Islam. Ultimately, the purpose of this study is to entrench the idea of religious statecraft as a function of Ethiopia's Christian history. This goal will be achieved through document analysis (cf. Bowen 2009:27). Compositely, cultural historiography and the principle of enculturation and self-definition are implied (Danto 2008:17; Rukuni 2018:156).

Firstly, the Kebra Naghast introduces the biblical glory of Ethiopian statecraft, by attaching it to the central focus of the Old Testament 'Israelite theocracy' (Budge 2000:21; Gen 12:1-3; Ex 19:5). The chosen nature of the Israelite nation, as directly connected to the Deity and conceived as an action of divinely appointed patriarchs and prophets, overwhelms the Old Testament narratives. In a related discussion, the biblical account of 1 Kings 10 is a reality attested to by historicity, although certain elements derived from Ethiopic tradition are left out in the Old Testament narrative. The claim for a Solomonic descendent, Bäynä Ləhk $ə m$ or Menelik I, sets the background for the whole record of the Kebra Naghast (Bausi 2009:266). Menelik I is accompanied by the claim of Ethiopic succession to the Israelite theocratic privilege (Kebra Naghast 32, 36, 55; Budge 2000:34, $40,71)$. The Ark of the Covenant and correspondingly the Ten Commandments come to be identified with the return and reign of Menelik I (Budge 2000:iv). In other words, the distinctive features that 
defined Israel, the Decalogue and the Divine presence, have shifted to Ethiopia (Munro-Hay 2006:69-130, 173-195).

It has to be decoded what the Ark and its contents resembled and implied. The Ark of the Covenant was the guarantee of God's favour upon Israel, basing on his presence (Ex 25:8). There are certain Zionist themes that can be derived in assertions made here. The Israelite nation, from its conception as in Exodus 19, where there is mention of the Covenant and its establishment between God and the people, was defined to a certain degree by military conquest. Arguably, a greater number of these wars were for survival rather than usurpation. The deliverance from Egyptian slavery had been completely divine (Ex 15), whilst taking Canaan would employ both divine and outright military stratagem (Jos 5). Coupled with this would be emphasis upon rededication of the people to God and a reminder of his presence amongst them. Because of its centrality in certain battles (Jos 3:8-11, 16-17, 6:6, 1 Sm 4:5), when derived thematically, the ark does hint at a religious-martial identity. Therefore, Menelik was signatory to Ethiopia becoming a nation under divine law and military superiority. There would be nobility in conquests pursued by the nation under God's blessing.

It has to be noted that the implications of this Judaic impression are thereby traceable to Aksumite Christian monarchs such as Ezana, MHDYS and Kaleb. Their religiomartial personas can be discussed under the subject of Constantinianism. There are multiple instances of conflict within the narrative of Ethiopia where there is an explicit combination of religion and military conquests, some of them being intrareligious, such as the clash with Islam, Catholicism and internal dynasty clashes (Boavida, Pennec \& Ramos 2011:2:196; Hassen 2015:253-254; Tamrat 1972). However, there is an explicit account of religious-political import that shows the impressive nature of the Kebra Naghast tradition upon the Ethiopian monarch.

\section{Menelik II: Constantinianism and Zionism in religious-martial policy}

Latter derivatives of this idea can be traced to Menelik II, the emperor who managed the stand-off with the Italians at the battle of Adwa. Menelik II managed to derive a religious aura from his identification with the historic emperors who are chronicled in the Kebra Naghast. Menelik II succeeded emperors who claimed descendance from Solomon, namely Tewodros and Yohannes (Ruebenson 1966:48). Regarding the intrinsic blend of martial and religious policy, there are intrinsic references in accounts of the battle at Adwa. It is recounted that Menelik II was in a church the day of the Italian offense and would not be disturbed by anything until the service's conclusion (Prouty 1986:155). In addition, there was the coincidental presence of the Aksumite clergy who had brought with them the tabot (equivalent of the Ark) of Mary as a spiritual affirmation of the holy cause of the king's war; Menelik II himself was said to have always carried the tabot of St George, the intrinsically militarised saint (Pankhurst 1989:78-103; Silverman 2005:84).

The availability of the clerics in the vicinity of the battlefield and the explicit knowledge of the presence of the tabot was arguably a psychological boost to the armies of the Ethiopians. The king's projection as a pious man who would not substitute divine favour for prompt military response denotes the whole narrative as religious. The parallels from Israel are striking; perhaps it would also be useful at this juncture to review the medieval relationship between ascetics and the monarch, which in turn paralleled the Abuna and the Negus. By extension in the comparison is the fact that Constantine carried his mosaic tabernacle to the war against Licinius (Soc. HE I.18.12, Schaff 1885c:48-49; Soz. HE I.8.10, Schaff 1885c:348; VC II.12.1, Schaff 1885b:759-760).

This section discussing Menelik II and the commentative use of his narrative is an attempt to reconcile Ethiopian ideology regarding religious statecraft with the Israelite components of theocracy and extendedly Zionism. However, in pursuit of diverse authorship on the subject, the parallels with Constantine are striking; perhaps, this is a consequence of the impact of Constantine's religious empire upon all latter phenomenon relating to the church and state. Notably, in his record of Orthodox Tawahido Christian tradition and history, Isaac initially brings to attention that the Kebra Naghast was central to the ecclesiastic-monarchical power matrix. The Judaic-Christian tradition of Ethiopia held eminence over both church and monarchy (Isaac 2013:136). The Negus' influence was bound in his identity with the church; the resurgence of the notion of a Solomonic dynasty in 1270 was masterminded by the clergy (Binns 2017:49; Crummey 2004:192-193; Piovanelli 2014:690). The claims to legitimacy were morphed into propaganda, as reflected in the Kebra Naghast. The ascetic Tekle Haymanot was behind the rise of Yekuno-Amlak to power, after which the Negus (Yekuno) created the office of Itchege (the grand prior). Tekle Haymanot became a Eusebius for the emperor, acting as his councillor and confessor (Isaac 2013:136-137).

\section{The divine monarchy as a function of the church-state establishment}

Isaac's account of imperial inauguration by church power figures also implies the manner in which a religious-state agenda was primary (Isaac 2013:137). Below is a summative overview derived from Isaac (2013):

The proceedings are said to have commenced with the reading of the book of Psalm 122 and just about the end there would be a chant of Psalm 110. In between the Abuna would present the respective monarch as a descendant of Menelik I. Explicitly the Abuna would recount how he (Menelik) was 'the first-born son of Solomon and the Queen of Sheba', the dynasty which had been perpetuated without any interruption to the very day of coronation. The Negus would then be handed a sword titled the 'Sword of Solomon', whilst being charged with the execution of true justice, protection of the church, the vulnerable, restoration, 
punishing the wicked, honouring the righteous and ultimately serving the Saviour Jesus Christ. The concluding sentence implicatively assigns a religious agenda to the king as the Abuna charged the Negus, 'may you by our prayers ... inherit the crown of eternal life. Amen'. (p. 137)

The use of Psalm 122 infers the transfer of the glory of Jerusalem to Ethiopia. Whilst it celebrates the reign of David

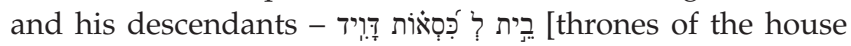
of David] - the passage recounts Jerusalem as prosperous and as blessed with the Divine presence. Therefore, the city's primacy is derived from the reality of the Divine presence. Mutually, the city is flourishing in a prosperous and peaceful reign under the blessed monarchy of the Davidic dynasty. There is the recurrent theme of piety and power, the base idea for the notion of religious statecraft (cf. Tabaar 2018). Deductively, Zionism then derives the code for a theocratic nation with a divinely sanctioned secular agenda (cf. Novak 2015). By extension as correspondent with Kebra Naghast tradition, the Ethiopian Negus was to actively maintain the principle of a divinely sanctioned prosperity and peace policy. Deductively, peace and prosperity would entail the agenda for holy wars and prosperity the infrastructural-social policy, as per the advice of the church (Book of the Himyarites, Moberg 1924; Stoyanov 2014:383; Webster 1980:3-35).

The passage Psalm 110 implies a blend of military, political and religious roles. In light of the derivate approach by the Ethiopian-Solomonic monarch, where Israelite scriptures are decoded as of intrinsic import and application in the socio-political terrain, certain observations are notable (Piovanelli 2014:690). Within the passage, the divine priestkingly and military figure Melchizedek (măl-kî-șéédéq /

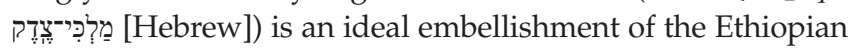
Negus. Whereas the title of 'priest' is applicable because of the religious functions, dually the titles of 'king' and 'commander'

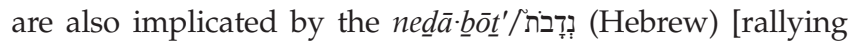

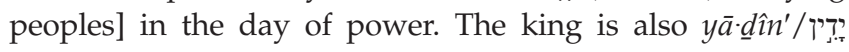
[judge] of the gô.yim/a [heathen peoples]; he triumphs over these and many 'ě'rěș ארֵץ [nations/countries].

The other account of the coronation is illustrated in the Ser'ata-Mangest [Order of the Realm] (Doresse 1959:14, 15; Isaac 2013:138). The Emperor, mounted upon a horse, arrays himself before a group of women titled the daughters of the city; they prevent his further movement with cord. Repetitively, they proclaim three times in the King James Version-like Psaltery language, crying, 'truly, truly, you are the King of Zion, a descendant of David and of Solomon'. After this, the king is granted passage onto what is known as the throne of David and thereafter coronated.

Both narratives are arguably derivative of Judaic tradition. The impression of the book of Psalms is explicit. This shows the case for an intrinsically religious state in the Ethiopian religious-political psyche. The Judaic-Christian conditioning of Ethiopia implicatively impresses the whole national narrative with a parallel Zionist-Constantinian agenda. In other words, the manner in which the references to Judaic tradition enhance the comprehension of religious statecraft develops a case for a reflection on Zionism, whilst the Christianisation of politics implies subsequently a parallel review of Constantinianism. Correspondingly, the focus is upon the Judaic-Zionist derivatives within the Ethiopian religious-political psyche.

\section{Zionism and derivatives for Ethiopian statecraft}

David Novak conceptualised Zionism as the intrinsic justification for and belief in an Israeli state (Novak 2015:124). Given the manner in which Ethiopia derived from Hebraic tradition and the preceding discussion regarding the ecclesiastical and political establishment, the conceptualisation of a religious nation was enforced mutually by the Christian and Jewish traditions. The Jewish argument for a theocracy derives from the understanding that a theocratic nation is a communal assembly that recognises the authority of God (Klatzkin 1918:15-16). Using the parallel of Cain, who went away from the Lord [mi-lifnei adonai] (Gen 4:16-17), versus Enoch (hanokh [dedicated one]; Gen 5:24), a case is made for a secular and godly polity (Kasher 1992:358-60).

In ancient Israel, principally there was a symbiotic attachment between the human institutions of the priesthood and the political establishment (Am 7:12-17; Spiegel 1958). The extreme example of political alienation from the Deity is the babel initiative of Genesis 11:1, where there was a convergence based on intransigent refusal of divine claims. There was an existent unity based on linguistic uniformity (safah ahat [one language]), with engineering intent so as to make a legacy shem [name] (Novak 2015:125). The Zionist mindset regarding God and human polity is expressed in the idea that unity amongst humankind is acceptable to the extent that it falls under God's universal sovereignty. That is, eschatologically God would establish a nation of humanity serving him with harmony [shkhem ehad] (Zph 3:9). Ultimately, there are universally applicable laws (Jonas 1977, 1984:140).

The universal agenda of God stems from the fact that religion cannot be privatised but is rather communal, hence the overtures towards becoming a religious nation (Hotam 2008:70). The religious affairs of Israel are taken to be a public matter (Wittgenstein 1958:88-89). Non-Jews are invited rather to practise what has been always common to them as a right in the form of natural law, or rather the Noahide commandments. To enforce these becomes the possible role of the secular arm of a religious state (Funkenstein 1986:12-22). Noahide commandments consist of issues such as murder, incest and robbery (Novak 1998).

The preceding discussion poses an intricate scenario when reflected upon from the perspective of the Judaic nature of the two antagonistic nations the Arabian Himyarites and the Aksumites. Both made claims of an imperialist nature, with 
Aksum preceding Himyar to this effect. If the pre-Christian Judaic Ethiopia is a historical fact as established in other discussions, arguably the wars for territorial presence could have been also impressed with a religious agenda - that is, one to bring pagans under law; this theory becomes problematic from the perspective of a denotation of preChristian Ethiopia as pagan/animistic, taking after Kush (Sima 2007:661-2.). However, departing from the preChristian Judaic influence as a platform would infuse a religious nationalistic idea upon Ethiopian military campaigns; this would be essentially reflective of the principle of Zionism that advocates for a Jewish polity.

It has to be noted that the reality of the anti-Judaic sentiment in the Kebra Naghast 93 (Budge 2000:143; Shahid 1976:140) and the Book of the Himyarites XXII.36b-37a (Moberg 1924:126-127) does not consist of the 2nd-century Common Era (CE) Hellenised anti-Judaic sentiment that characterised Roman Christianity (Nickelsburg 2003:195). Rather, it has to be established that this was a consequence of the persecution of Christianity by Judaic elements in Himyar and the correspondent regional rivalry for superiority (Nebes 2010:27-59). To a certain degree, this Zionistic impression could be deduced as its ideological defence against the invasion of Sharia law/rule under Arabic-Islamic conquests in the 7th century and onwards (Brett 1987:506; Wilhite 2017:321). After all, the Arabic conquests, more than being a military assault, were an ideological one. Therefore, resilience against the Islamisation of Africa in Ethiopia had to be based on more than a military stratagem.

\section{Defining statecraft against the backdrop of Islam}

The narrative regarding the rise of Islam and its spread upon the Arabian Peninsula emerges as a post-Kaleb account. This was the inception of another era, a definitive one for Ethiopia's immediate and outer region. Arguably, the integrated narrative of Ethiopian history would be incomplete without reference to the rise of Muhammed (HowardJohnston 2010:397). This is arguably premised on the intricate attachment the nation of Ethiopia has with the emergent 7thcentury Islamic phenomenon. The first connection is direct, as recounted in the traditions of the Hadith, where Ethiopia appears in a favourable light during the rise of the prophet. The second is the impact of Islam on Ethiopian regions of influence, primarily Himyar, the Eritrean and Sudanese regions, and Egypt. Despite the ascension of another power on the Arabian Peninsula by the Persians, in such a manner as to eclipse the gains of Kaleb - the religious cultural connection between Himyar and Ethiopia remained significant.

Alternatively, significance has been assigned to the Roman Persian war as the definitive setting for the rise of Muhammed (Howard-Johnston 2010:397). Whilst these approaches have been and are taken by notable scholars who have done extensive work on these subjects, the research continues with the angle that implies the issue of religious statecraft as a lens. Having embarked on an extensive discussion regarding the impressed Zionism in Ethiopian religious statecraft, here the heuristic model is implied upon the discussion of Islam and Christian Ethiopia. Therefore, the research will approach the Islamic-Ethiopian narrative from the angle of relations between the two religions as political-religious establishments.

As noted earlier, the geographical connection between Ethiopia and Islam stems from Aksumite activity on the Red Sea (Robinson 2004:111). There was an Ethiopian presence in Mecca contemporary with Muhammad (Robinson 2004:111). Amongst the Ethiopian population at Mecca were both Christians and followers of Muhammad; there is a story of a certain Bilal who was committed to the Islamic cause, to the extent of joining the jihadist ranks in the conquests for Syria and Iraq (Robinson 2004:111). As Muhammad was conceiving a community of believers recruited by a public evangelisation, his message was antagonistic to the traditional religions of Mecca, thereby becoming a target for persecution (Life of Mohammed 183-185, Guillaume 1955-1998:130-131). So as to avert the persecution of his pioneer followers and kinsmen, he arranged asylum for them in the Christian kingdom of Aksum (Hadith Bk. 37: Transference of a Debt from One Person to Another [Al-Hawaala] 3.494: Narrated Aisha). This was premised on goodwill that would be because of them as fellow monotheists. In the years 615-616 CE, there was a dispatch of 100 plus Muhammadan faithfuls into Ethiopia (Guillaume 1955-1998:146-148; Robinson 2004:111; Life of Mohammed 208-215). The asylum was of a political religious nature, as it is associated with Muhammad's family members receiving a form of diplomatic protection; as mentioned, there was Ruqayya (the prophet's daughter), her husband Uthman (a future Islamic leader) and his future wife Umm Habiba (Muir 1923:70). It is said that the Aksumite emperor protected these high-profile refugees against overtures from the Meccan Quraish who intended to have them extradited through Abu Rabi'a and 'Amr b. al-'Asb. Wa'il (Life of Mohammed; Guillaume 1955-1998:150-153). This event is celebrated in Islamic tradition as the first and second hijras to Abyssinia (Guillaume 1955-1998:146, 526-530; Robinson 2004:112; Life of Mohammed 217-221).

Ethiopia is composite to Islam's origin narratives that are morphed into instructive doxology. After the prophet secured ground in Medina $622 \mathrm{CE}$, the cooperation of the Negus is recorded in how he is said to have promptly repatriated the Islamic nobles and the respective community (Isaac 2013:191; Robinson 2004:112). The followers of Muhammad arrived in Medina in the year 628 CE with evidence of the emperor's liberality in the form of treasures; from this treasure, Umm Habiba, who had been divorced from her husband (then a Christian convert choosing Aksum), salvaged a dowry to marry the prophet (Life of Mohammed 918; Guillaume 1955-1998:793; Bk. 58: Merits of the Helpers in Madinah [Ansaar] 5.124). It is then recounted that Muhammad's wife and another accomplice of hers during the asylum experience had illuminative memories of Aksum as a holy place glorified 
by edifices to the saints' honours; these were presumably the comforting tales that the prophet listened to as he lay dying (Hadith Bk. 23: Funerals [Al-Janaa'iz ] 2.425:Narrated 'Aisha).

There is also a reference in some hadiths to a declaration by the prophet that shielded Aksum from the conquests. Robinson explains how this accordance of neutrality from jihad titled the Dar al-Hiyad for Aksum corresponded to the exemptions upon Muslims and Arabs (Robinson 2004:112; Wilhite 2017:326-329). This would be out of regard for the Aksumite asylum for the Muslims. Another tradition implies a secret Islamic conversion by Negus al-Asham b.Abjar, as implied in his acceptance of the superiority of Islam - similar to the Catholic conversion by Suseysnos later on - and Askumite military assistance in the takeover of Mecca (Life of Mohammed 1569; Guillaume 1955-1998:657). The preceding assertion does not seem to have correspondence with the Aksumite legacy; however, this leaves room for further investigation from the perspective of the decline that was experienced in the regional significance of Ethiopia at this time. In addition, this was a war by religious refugees, monotheists who wanted to establish an anti-pagan society within the Arabian Peninsula - a possible cause for the Negus' holy armies. Correspondingly, the narratives of Abraha's attempt to destroy the Ka'ba imply an acknowledgement of Aksumite-Himyarite military superiority that is juxtaposed against the emergent religious superiority of Islam (Life of Muhammad 31-34; Guillaume 1955-1998:23-25).

The narrative of an Islamic Negus could be true or not, based on the lack of substantial evidence available. Alternatively, Islamic scholars were deriving their accounts from the narratives of Aksumite glory in Himyar, as discussed in the imperialist foreign policy that composed the narrative of global geopolitics at the time. The Aksumites for a fact had exercised considerable influence over the significant kingdom of Himyar on the Arabian Peninsula; to concretely blend their narrative within the origin story of Islam was useful propaganda (Hadith Bk. 23: Funerals [Al-Janaa'iz] 2.406: Narrated Jabir bin 'Abdullah). This furthers the substance of reviewing conversations between Christianity and Islam at this juncture, more especially Syriac Christianity, which has connections to Ethiopia.

Therefore, with regard to the 6th and 7th centuries, which saw the rise of Islam, Ethiopia held a relationship of cordiality, it would seem. This would be based on its involvement in the origin tradition of Islam. Reiteratively, it should be noted that the reaction of Ethiopia to the rise of Islam is relevant against the background of its geopolitical significance within the Red Sea region and mutually the geographical location of Islamic origins upon the Arabian Peninsula. There is an alternative theory as to the possibility of early hostility; however, this is confronted by the apparent connection suggested in the Islamic origin traditions (Robinson 2004:113). Arguably, an agreeable theory would be the correlation between Ethiopian Christian-Islamic relations and the global dynamics of jihad versus crusade. This is so especially because both the notions of crusade and jihad represented more than religious conflict; they were the ideological basis for a case of religious statecraft (cf. Tabaar 2018).

The relationship between the two institutions became hostile with time, as evident in the narrative of Ethiopia, where there would be a struggle between a Christianised state and Islamic elements. Perhaps a notable factor in the dynamics of relations between Islam and Christianity in Ethiopia is how essentially the notion of religious statecraft was a major determinant. Retrospectively, Menelik I, as a character of the Kebra Naghast, has been deduced as an emblem of the Judaic Christian complex that defined Ethiopia's religious-political matrix. The assertions put forth in the research find affirmation in this regard; the capacity of Ethiopia to withstand regional religious-political dynamics in the form of Islam, and later Catholicism, can arguably be assigned to the characterisation of Ethiopia as a religious state (Boavida et al. 2011). The preceding assertions derive from the reality of how Islam found its existence on the Red Sea and Mediterranean world; this was an emerging religion and simultaneously a political power. Via trade, the Kharijite, Shia and Sunni repeated Christianity's economic entrance story on the eastern African coast (Robinson 2004:113).

\section{Dialogue between Islam and Eastern Christianity}

Another insightful issue is the review of the interaction between Islam and Eastern Christianity. It must be reiterated at this stage that Ethiopia has been established to have had connections with Eastern Christianity. Eastern Christianity also bears relevance because of the geographical proximity between Mecca, Medina (cities within the Arabian Peninsula) and the regions of Eastern Christianity. Therefore, this analysis enhances the understanding regarding the initial response of Christianity to the inceptive stage of the origins of Islam and the Arabian conquests (Penn 2015). The preceding is a result of the fact that a case for initial contact between the two institutions is substantiated in view of the response of Eastern Christianity to Islam as the earliest record of contact between Islam and Christianity.

It has to be noted that regions of Eastern Christianity such as Syria were not spared from jihad in the same manner that Ethiopia was exempt during the first wave that characterised the Islamic origins. This goes a long way towards establishing the tone of hostility that pervades the respective literature, such as the apocalyptics Pseudo-Methodius and Eddessene. These works index a retaliatory personification of Islam as the ultimate Christian antagonist (Olster 1994:123-125, 180-182), thereby meriting divine wrath in the same manner befitting enemies of the biblical Israelite theocracy. Deductively, Islam is ascribed titles akin to how Israelite foes were at times depicted as representing Satan/the Devil, God's enemy (Ezk 28; Is 14). This clearly could not be in sync with the already-discussed relations 
between the emerging Islam and Ethiopia. However, it has to be established that this polemic was characteristic of clashes between religious statecraft, the mentioned examples being Constantine against Licinius and Kaleb versus Yusuf/Masruq (Rukuni \& Oliver 2020).

Relations between Ethiopia and Islam, however, shifted in the 1000s, and substantial conflict and meaningful retaliation for jihad were definitive characteristics of the then-emergent Solomonic dynasty of 1270 (Friedlander \& Friedlander 2015:112). It should be remembered that the Kebra Naghast is ascribed to the clerical monarchical connection of Yekuno Amlak (Piovanelli 2014:690). The Kebra Naghast in its ideological exaltation of the Ethiopic legacy parallels the two mentioned apocalyptic works, Pseudo-Methodius and the Eddessene apocalyptic. Whilst these works are Eastern in origin, it has to be noted that Ethiopia is a significant element within their ideology (Piovanelli 2013:15). Ethiopia was the Christian champion of late Coptic tradition and a regrettable idea to early Arabic apocalyptic works (Piovanelli 2013:15). There is more than a passing mention of the nation; Ethiopia is both directly and indirectly depicted as part of the solution to the Islamic threat upon Christianity.

Notably, because the suggested date of the authorship of these apocalyptic works is late $600 \mathrm{CE}$, specifically $692 \mathrm{CE}$ in the case of Psuedo-Methodius, this arguably suggests that Kaleb's victory over the forced Judaization of Christians in Himyar was an ideological locus from which the work derived. Kaleb, the embodiment of piety and power, somewhat of a self-conscious second Constantine in his version of religious statecraft, was a worthy rallying centre for Syriac Christianity (Munro-Hay 1991:88). This is possibly a result of the classification of Ethiopian Christianity as aggregately Eastern in line with its Syrian connection; it formed part of the Melkite orthodoxy connection (Griffith 2004:68-72; Martínez 1990:249-56). This raises the stakes from the perspective of how influential the Pseudo-Methodius was as a rallying agent for an ideological response to jihad throughout both Eastern and Western Christianity. The extent of the influence of Psuedo-Methodius is substantiated by the subsequent translation of the source into both Greek and Latin (Stemberger 1999:265). In addition, another definitive feature is how the jihad saw a reversion of Christian ideology; there is an apparent give and take in the content of PseudoMethodius regarding the relevance of Judaism. It has to be noted that Christianity had undergone a 2nd-century CE detachment from Hebraic elements in the Jewish-Christian schism (Boyarin 2004:26-27; Rukuni 2018:38-54). Although Eastern Christianity showed relative Judaic strands when compared to Byzantine Christendom, there was a case for anti-Judaic sentiment as a result of alliances between Judaic Arabs and the Persians, which saw hostility against Christians on the Arabian Peninsula and in the East (Nebes 2010; Stoyanov 2014:400). Persia was a persecuting power from the perspective of the reign of Shapur II. However, the other anti-Semitic stance could have been a consequence of the traditional hatred against the Jews for the crime of deicide as represented in Nicene Christianity (cf. VC 3.18.2-4; 19.1, Schaff 1885b:793, 794; Tertullian On Prayer 14; Schaff 1885a:276-277; Barnes 2011:124-125).

According to Pseudo-Methodius, the coming of the Islamic conquests was foreshadowed in Gideon's conflict and subsequent victory over the Ishmaelites and Midianites (Penn 2015:109). From this perspective, the kingdom of the Arabs becomes an eschatological scourge, a crucible for Christianity (Pseudo-Methodius XI.25-27; Penn 2015:118-119). The manner in which Pseudo-Methodius locates the advent of the Arabs onto the world stage is implicatively derived from the schematic imperial phases that characterise Daniel 2 and 7. Daniel's prophesies constitute a chronological Israelite philosophy of religious statecraft. That is, the world's secular history is juxtaposed with the narrative of a religious nation that would become the universal power eschatologically. Therefore, reference to other competing powers becomes secondary to the story line that ultimately results in the elevation of the godly nation. In the discussion's reference in Pseudo-Methodius to Persian power, the Islamic invasions can be deduced as a composite momentum to the rise at the end of the orthodox Christian power that will surrender power to Christ in Israel (XIV.44-45; Penn 2015:127).

Pseudo-Methodius had a cross-confessional appeal, as evidenced by the existence of versions in Miaphysite, East Syrian, Greek, Latin, Armenian and Slavic (Penn 2015:112). The work exalts a Byzantine ruler as the Christian champion against Islam at the end who would fulfil Psalm 68:31, a prediction of Kushite/Ethiopic magnanimity (Martínez 1985:136; Penn 2015:113). The verse was of importance to the Miaphysite confession. The involvement of Ethiopia was not to be direct, as the Byzantine ruler to ultimately conquer the Arabs would be of Kushite/Ethiopic lineage (Penn 2015:114). Therefore, the hero of Pseudo-Methodius is rather an ecumenical figment of Byzantine-Ethiopian composition. This is deductible as an envisioned united Christian front that was to counter an extensive militarised religious ideology, that is, Islam. This would be sensible with respect to the glorious military alliances between Aksum and Byzantium in defending Christian states against Judaization. In addition, there was a need for a unified rallying ideology for Christians, who were stratified along doctrinal schismatic lines.

The preceding arguments conform to the notion that Pseudo-Methodius was a reaction to the consolidation of the Umayyad Dynasty and the consequent public proclamation of Islam as the superior religion (Brett 1978:506). The extent to which the Ishmaelites' reign was characterised by extensive pillaging, enslavement and taxation merited a military response, so as to establish an alternative religious state (Pseudo-Methodius V.8-10, XI.27; Penn 2015:116,119). The imminent assumption of power by the Islamic kingdom was supposedly divine wrath for the level of decadence and abominations then prevalent amongst Christendom. Therefore, because of this, Persia, Sicily, Syria and Rome would be given over to Destruction and Annihilation 
personified, which parallels the apocalypse's Abaddon and Apollyon (Rv 9). Concerning Egypt and Syria, the burden of taxation would be exerted (XI.27).

The sons of Ishmael were barbarian tyrants set on personified annihilation and devastation; they were personified defilement, destroyers of inanimate creation, murderers of pregnant women and baby killers (XI.31, 32; Penn 2015:121, 122). The sons of Ishmael were going to kill the priestly caste and deacons in the holy places, desecrate the holy places by having sexual relations with the wives of their victims and other captive females in the sacred Christian locations. In addition, the violation of the Christian faith would also comprise the common use of sacred vestments/clothes and disrespect for the martyrs' sarcophagi and the graves of the saints (XI.31, 32; Penn 2015:122).

Another look at the alleged crimes of the sons of Ishmael intrinsically substantiates a case for a battle in the restoration of Christian statecraft. This conclusion is qualified by alluding to possible derivate sources and narratives for the apocalyptic work of Pseudo-Methodius:

- The personification of the sons of Ishmael as Devastation and Annihilation parallels the reference to the Satanic work of destruction in Revelation 9; hence the ascription of the title of devastators implies categorisation of the sons of Ishmael as the epitome of Christian antagonists.

- The killing of babies and pregnant women were events associated with some of Israel's sternest of prophesies issued by Moses ( $\mathrm{Lv}$ 26:28). Also, Israelite history recorded the cruelty of pagan kings murdering children, from Pharaoh's depopulative policy to Herod's response to the birth of Jesus (Ex 1:15; Josephus Anti.II.9.2, O'Bannon 2016:132; Mt 2:16). The 70 CE destruction of Jerusalem also saw terrible circumstances for mothers and their babies at the hands of pagan Roman soldiers. By all means, this was a crime against humanity (Josephus Wars II.14.9; O'Bannon 2016:1244). These kinds of hostilities also implied the fall of these pagan monarchs.

- The desecration of sacred vestments and the holy relics in the form of the tombs of the martyrs had been a cause for the visitation of divine wrath in Babylon the night Belshazzar was conquered by the Persians (Dn 5). In addition, Constantine's war with Licinius was mainly premised on similar attacks by Licinius against the Christian clergy.

These crimes were exerted upon the whole of Christendom, leaving only one conclusion: Here was a common enemy against all Christendom. Exceptionally, the Byzantine kingdom and the Ethiopian kingdom are not mentioned in those subjugated. This thereby implies that they would emerge as the universal heroes. When these facts are analysed, it has to be noted that these points constitute the argument for a divine martial response. There had to be an ideological consensus that Islam was a common enemy to Christendom and that a military response was religiously merited.
This would be a holy war. This corroborates the idea that religious statecraft aggregately precedes religious conflict. Alternatively put, religious statecraft as an ideology fuels religious conflict.

\section{The emergence of a religious- martial policy}

The retributive acts of the king of the Greeks upon the sons of Ishmael would essentially constitute retaliatory action, pound for pound. Therefore, here is another scenario where genocide would be welcome, as it was premised on the notion of redemption of the cause of Christianity. It is within this context where there is reasonable ground to argue for the Book of the Himyarites as a derivate source for PseudoMethodius. The sons of Ishmael would correspondingly be subjugated, endure slavery and many of them be put to the sword (XIII.39, 40; Penn 2015:125).

The Christians had to find a way to decode the widespread influence and conquest of Islam; this could only be a sign of the eschaton. Hence possibly the manner in which the apocalyptic work blends the millennium of Revelation 20, where there will be a respite for the saints in the heavenly Jerusalem and a conclusive universal war after 1000 years. This adds to the momentum of the involvement of Ethiopia in the apocalypse, as it implies a universal recognition of the military victory of Ethiopia in the Himyarite war with forced Judaism. This was an event of the 6th century CE. In addition, there is a notable cross-triumphalism that defines part of the end narrative that argues for an impressionism of Constantinian narratives and the Book of the Himyarites.

The hero of the story, the Greek monarch, is portrayed as ascending and standing on Golgotha, the location of Jesus' crucifixion. The monarch would then restore the cross of Christ to the very same position it was in during the crucifixion of Christ. In a symbolic manner, the king would place his crown on top of the cross; this would be followed by divine events, where the cross would ascend into heaven bearing the earthly crown of the hero of Christendom. This action, together with the surrender of the king's soul, would subsequently abolish all secular earthly authority (XIII. 44, 45; Penn 2015:127). Therefore, this implied that this victory was crucial to Christianity, as it would entail the kingdom of their lord Christ. Retrospectively, this implies the campaigns of the emperor Constantine, which had been characterised by either a literal carrying of the cross insignia or an allusion to the cross as the source of victory (cf. Potter 2013:137-146; HE 9.9.10-11, Schaff 1885b:584; VC I.28-31, Schaff 1885b:740-742). Notably, this was a significant feature of all subsequent clashes with Islam, as was primarily revealed during the crusades (Richard 1999:218). The basis for a religious conflict had been religious statecraft entrenched in an ecclesiastical-political ideology (Stoyanov 2014:381-382). The wars of Constantine, the Himyarite war where Kaleb emphasised the victory as that of the cross rather than his own, index the intrinsically religious texture of the conflict (Book of the Himyarites 49b; Moberg 
1924:138). This was a conflict of national religious ideology; the dominant religion would determine the type of state and correspondent policy. This had to be emphasised by alluding to the desired victory as belonging to the cross.

\section{Conflicting statecraft: Islamic threat and the Christian kingdom}

Ethiopia soon found itself surrounded by Islamic kingdoms in the lowlands (modern day Eritrea, Djibouti and Somalia); the peak Islamic presence was during the 16th century, when Muslims constituted about one-third of the population in the highland regions of Ethiopia (Robinson 2004:114). It seems that Islam followed the blueprint of Ethiopian Christianisation in several regards other than the use of trade; the Alexandrian connection entailed ideological influence through the Fatimids' Islamic university (Robinson 2004:114). In addition, so as to retain the connection with Egyptian Coptic Christianity, Ethiopia was now at the mercy of whichever Islamic power controlled Egypt (Binns 2017:44). This ranged from the Fatimids to the Turks. Consequently, Islam was reshaping Ethiopian geopolitics; another related observation is how Ethiopia was cordoned off from international Christian allies. This was a result of Islamic control of the East African coasts (Trimingham 1965:47-48).

Kaleb, the 7th century war hero, is an embellishment of religious and martial policy. This thereby connects him to the concept of Constantinianism (Long 2013:100-124). This is when Constantinianism is categorised as religious statecraft's reaction to religious conflict. The emperor Constantine definitively enjoined a Christian military policy in defence of the ecclesiastical establishment, both internally and externally. Constantine engaged Licinius and Shapur II, representing an internal conflict and an international one. Whereas Licinius had become the sole impediment to sole imperial rule, Shapur II represented an untenable balance of power between the Persian and Roman empire (Potter 2013:145; Smith 2016:21). The attack on Christians and their infrastructure by both Licinius and Shapur II entailed that these two were not allies and thereby were enemies of the emergent Christian imperium (Cureton 1864:72-85). In addition, the explicit paganism and Zoroastrian stance of these antagonists gave Constantine and his established political-ecclesiastical network a religious reason to pursue imperial dominancy (Cameron \& Hall 1999:320; Rapp 1998:685; VC IV.13, Schaff 1885b:822). The preceding background defined Roman-Byzantine geopolitics, a precedingly discussed parallel being Ethiopian practice in the Arabian kingdom of Himyar.

The Islamic crusades signally conquered the Dahlak archipelago, which then functioned as a springboard for Islamic entrance into East Africa (Trimingham 1965:47). This conceived in a way a reversal of the expansionist policy that had characterised the reign of Christian monarchs Ezana and Kaleb, as this saw Ethiopia lose territory. The end effect, as mentioned, was a loss of the strategic coasts that had connected Ethiopia to the rest of Christendom
(Trimingham 1965:47,48). After this, Islam entered a phase of expansion on Ethiopian soil until 1270; the resurgence of the Solomonic dynasty meant the consolidation of a formidable challenger (Isaac 2013:192). The reorganisation of the ecclesiastical-aristocratic establishment meant the existence of an alternative religious statecraft to the Islamic sharia, which could have already been practised in Ifat, Adal, Fatagar, Dawaro, Bali and other eastern and central Ethiopian regions (Isaac 2013:192).

These states had challenged the authority of the emperor prior to $1270 \mathrm{CE}$, when there was a consolidated response to the Islamic expansion. It seemed that the respite that characterised the era before the rise of Yekuno Amlak was premised on a cordial submission by the Islamic states, where they would pay taxes and not revolt against the Christian empire (Isaac 2013:192). This seemingly was untenable; therefore, there was an uneasy peace. This has been construed by scholars not as a religious war but rather as a political conflict. Although the conflict is categorised as political, the clash of religious ideologies is implicatively a definitive background. This thereby makes it a war between Islamic and Christian statecraft. So as to restore the patriarch-Abuna connection with Coptic Egypt under Islamic control of Egypt, Ethiopia had to conduct raids on South Arabian Islamic traders and the Islamic state of Adal as leverage, to engage the Egyptian sultan's attention (Trimingham 1965:64).

Ethiopian Christian-Islamic policy vacillated between offenses and toleration-inaction; this was reactionary to Islamic hostilities. Yagbe'a Sion (1285-1294) managed a popular Ethiopian Islamic policy, whilst Amde Tsion I (1314-1344) oversaw an intensified martial counter policy against the Islamic states of Ifat and Adal (Isaac 2013:193). According to Isaac, Islamification in Ethiopia thrived on the passive Ethiopian policy of toleration and inaction rather than the success of conquests (Isaac 2013:193). Ethiopia's Christian-Islamic policy remained significantly reactionary; it would appear as Sayfa Arad (1344-1372) in 1352 exercised an interventionist policy in Egypt. This was a countermeasure to the persecution of Christians in Egypt by Sultan al-Malik as Salih (Perruchon 1893:177-182). This was arguably a continuation of the passive policy; given the relaxed control over internal Islamic states in Ethiopia, which sporadically revolted, a foreign interventionist policy would clearly not imply an intended offensive but rather the securing of a timely truce. Ethiopia wanted peace for Christians, it would appear, and not the annihilation of Islam. This is the perspective of a writer who is corroborating a Christian narrative of the Orthodox Church; therefore, this can be discredited by the opinion of an Islamic author.

\section{Conclusion}

A review of Ethiopia's religious-martial history points to Constantinianism and Zionism. Whilst Ethiopian statecraft was shaped by its Judaic-Christian history, it appears that 
there are implications for its relations to Islam; correspondingly, this is holistically perceivable when placing Ethiopia within its regional sphere of influence, which includes eastern Christianity. Notably, there is an impressionistic element in the narratives of Ethiopian religious-martial policy that highlights the influence of greater Christendom. Therefore, through these lenses, multiple deductions become possible in the case of resistance against Islamisation. More especially because a substantial amount of Ethiopian Christian-Islamic conflict took place after the era of the Crusades, the international conflict between the two religions could have likely shaped Ethiopic-Islamic tensions. However, given the manner in which Ethiopia's narrative was characterised by autonomy, it is possible to infer that as a nation, Ethiopia had a unique arrangement, one that could have implied mutual cohabitation and conflict only under provocation. The closest discussion capable of substantiating these notions would be concerning Gran the Islamic military leader and the case of the Oromo (Hassen 2015).

\section{Acknowledgements Competing interests}

The author has declared that no competing interests exist.

\section{Author's contributions}

I declare that I am the sole author of this research article.

\section{Ethical consideration}

This article followed all ethical standards for a research without direct contact with human or animal subjects.

\section{Funding information}

This research received no specific grant from any funding agency in the public, commercial or not-for-profit sectors.

\section{Data availability statement}

Data sharing is not applicable to this article as no new data were created or analysed in this study.

\section{Disclaimer}

The views and opinions expressed in this article are those of the author and do not necessarily reflect the official policy or position of any affiliated agency of the author.

\section{References}

Barnes, T.D., 2011, Constantine. Dynasty, religion and power in the Late Roman Empire, Wiley-Blackwell, Chichester.

Bausi, A., 2009, 'Review of Beylot 2008, Aethiopica 12', International Journal of Ethiopian and Eritrean Studies 263-267.

Binns, J., 2017, The orthodox church of Ethiopia: A history account, I.B. Tauris, London.

Boavida, I., Pennec, H. \& Ramos, M.J. (eds.), 2011, Pedro Paez's history of Ethiopia, 1662 , vol. 2, The Hakluyt Society, London.

Bowen, G.A., 2009, 'Document analysis as a qualitative research method', Qualitative Research Journal 9(2), 27-40. https://doi.org/10.3316/QRJ0902027
Boyarin, D., 2004, Borderlines: The partition of Judaeo-Christianity, University of Pennsylvania Press, Philadelphia, PA.

Brett, M., 1978, 'The Arab conquest and the rise of Islam in North Africa', in J.D. Fage (ed.), The Cambridge history of Africa, vol. 2, pp. 490-544, Cambridge University Press, Cambridge.

Budge, E.W., 2000, The queen of Sheba and her only son Menyelek: Kebra Nagast, Ethiopian Series Cambridge Publications, Ontario.

Cameron, A. \& Hall, S.G., 1999, 'Eusebius: Life of Constantine I', in B. Bosworth, M Grin, D. Whitehead \& S. Treggiari (eds.), Clarendon ancient history series, University Press Inc, New York, NY.

Crummey, D.E., 2004, 'Ethiopia in the early modern period: Solomonic monarchy and Christianity', Journal of Early Modern History 8(3), 191-209. https://doi. org/10.1163/1570065043123940

Cureton, W., 1864, 'The martyrdom of Habib the Deacon', in Ancient Syriac documents, Oriental Press, Amsterdam.

Danto, E.A., 2008, Historical research, Oxford Scholarship Online, viewed 12 January 2018, from https://www.oxfordscholarship.com/view/10.1093/acprof:0 so/9780195333060.001.0001/acprof-9780195333060.

Doresse, J., 1959, Ethiopia, transl. E. Coult, Elek Books, London.

Friedlander, M. \& Friedlander, B., 2015, Hidden treasures of Ethiopia: A guide to the remote churches of an ancient land, I.B. TAURIS, London.

Funkenstein, A., 1986, Theology and the scientific imagination from the Middle Ages to the seventeenth century, Princeton University Press, Princeton, NJ.

Guillaume, A., 1955-1998, The life of Muhammad: Translation of Ibn Ishag's Sirat Rasul Allah, Oxford University Press, Oxford.

Griffith, S.H., 2004, 'Apologetics and historiography in the annals of Eutychius of Alexandria: Christian self-definition in the world of Islam', in R. Ebied \& H. Teule (ed.), Studies on the Christian Arabic heritage in honour of Fr Prof. Dr. Samir Khali Samir S.I. at the occasion of his sixty-fifth birthday, pp. 65-90, Peeters, Leuven.

Hassen, M., 2015, The Oromo and the Christian Kingdom of Ethiopia 1300-1700, James Currey, New York, NY

Howard-Johnston, J., 2010, Witnesses to a world crisis: Historians and histories of the Middle East in the seventh century, Oxford University Press, Oxford.

Isaac, E., 2013, The Ethiopian orthodox Tawahido Church, The Red Sea Press, Trenton, NJ.

Jonas, H., 1977, Das Prinzip Verantwortung: Versuch einer Ethik für die Technologische Zivilisation, Insel, Frankfurt am Main

Jonas, H., 1984, Der Gottesbegriff nach Auschwitz. Eine jüdische Stimme, Suhrkamp, Tübingen.

Kasher, M.M., 1992, Torah Shelemah 1, Beth Torah Shelemah, Jerusalem.

Klatzkin, J., 1918, Probleme des Modernen Judentum, Schneider, Berlin.

Long, D.S., 2013, 'Yoderian Constantinianism', in J.D. Roth (ed.), Constantine revisited: Leithart, Yoder, and the Constantinian debate, pp.100-124, Pickwick Publications, Eugene, OR.

Martínez, F.J., 1985, 'Eastern Christian apocalyptic in the early Muslim period: Pseudomethodius and Pseudo-Athanasius', PhD dissertation, The Catholic University of America, viewed 28 November 2019, from https://www.arzobispodegranada.es/.

Martínez, F.J., 1990, 'The king of Rum and the king of Ethiopia in Medieval apocalyptic texts from Egypt', in W. Godlewski (ed.), Coptic studies: Acts of the third international Congress of Coptic studies, 20-25 August 1984, pp. 247-259, PWN, Warsaw.

Moberg, A. (ed. \& transl.), 1924, The book of the Himyarites, Lund: Acta regiae Societatis humaniorum litterarum Lundensis, p. 7, London.

Muir, W., 1923, The life of Mohammed, Smith, Elder \& Co, London.

Munro-Hay, S., 1991, Aksum: An African civilisation of late antiquity, Edinburgh University Press, Edinburgh.

Munro-Hay, S., 2006, Ethiopia: Judaism, altars and saints, Tsehai, Hollywood, CA

Nebes, N., 2010, 'The martyrs of Najran and the end of Himyar: On the political history of South Arabia in the early sixth century', in A. Neuwirth, N. Sinai \& M. Max (eds.), The Qur'an in context historical and literary investigations into the Quranic Milieu, pp. 27-59, Leiden.

Nickelsburg, G.W.E., 2003, Ancient Judaism and Christian origins: Diversity, continuity and transformation, Fortress Press, Minneapolis, MN

Novak, D., 1998, Natural law in Judaism, Cambridge University Press, Cambridge.

Novak, D., 2015, Zionism and Judaism: A new theory, Cambridge University Press, New York, NY.

O'Bannon, K., 2016, Josephus: The complete works, Christian Classics Ethereal Library, Grand Rapids, MI.

Olster, D.M., 1994, Roman defeat, Christian response and the literary construction of the Jew, University of Pennsylvania, Philadelphia, PA.

Pankhurst, R., 1989, 'The Battle of Adwa (1896) as depicted by traditional Ethiopian artists', in Proceedings of the first international conference on the history of Ethiopian art, Pindar, London.

Penn, M., 2015, When Christians first met Muslims: A sourcebook of the earliest Syriac writings on Islam, University of California Press, Berkeley, CA.

Perruchon, J., 1893, Les chroniques de Zar'a Yâ'eqôb et de Ba'eda Mâryâm, rois d'Éthiope de 1434 à 1478 (texte éthiopien et traduction), É. Bouillon, Paris. 
Piovanelli, P., 2013, "The apocryphal legitimation of a "Solomonic" dynasty in the Kəbrä nägäśt: A reappraisal', Aethiopica: International Journal of Ethiopian and Eritrean Studies 16, 7-44.

Piovanelli, P., 2014, "'Orthodox" faith and political legitimization of a "Solomonic" dynasty of rulers in the Ethiopic Kebra Nagast', in K.B. Bardakjian \& S. La Porta (eds.), The Armenian apocalyptic tradition: A comparative perspective essays presented in honor of Professor Robert W. Thomson on the occasion of his eightieth birthday, pp. 688-705, Brill, Leiden.

Potter, D., 2013, Constantine the emperor, Oxford University Press, Oxford.

Prouty, C., 1986, Empress Taytu and Menelik II: Ethiopia, 1883-1910, Ravens, London.

Rapp, C., 1998, 'Imperial ideology in the making: Eusebius of Caesarea on Constantine as "Bishop"', Journal of Theological Studies 49(2), 685-95. https://doi. org/10.1093/jts/49.2.685

Richard, J., 1999, The Crusades: c.1071-c.1291, Cambridge University Press, Cambridge.

Robinson, D., 2004, Muslim societies in African history, Cambridge University Press, New York, NY.

Ruebenson, S., 1966, King of kings: Tewodros of Ethiopia, Haille Sellassie I University, Addis Ababa.

Rukuni, R., 2018, 'The schism, Hellenism and politics: A review of the emergence of Ecumenical orthodoxy AD 100-400', Master's dissertation, UNISA, Pretoria.

Rukuni, R. \& Oliver, E., 2019a, 'A case for organic indigenous Christianity: African Ethiopia as derivate from Jewish Christianity', HTS Teologiese Studies/Theological Studies 75(1), a5270. https://doi.org/10.4102/hts.v75i1.5270

Rukuni, R. \& Oliver, E., 2019b, 'African Ethiopia and Byzantine imperial orthodoxy: Politically influenced self-definition of Christianity', HTS Teologiese Studies/ Theological Studies 75(4), a5314. https://doi.org/10.4102/hts.v75i4.5314

Rukuni, R. \& Oliver, E., 2019c, 'Africanism, Apocalypticism, Jihad and Jesuitism: Prelude to Ethiopianism', HTS Teologiese Studies/Theological Studies 75(3), a5384. https://doi.org/10.4102/hts.v75i3.5384

Rukuni, R., 2020, 'Religious statecraft: Narratives of persecution and diplomacy in the case of Byzantine, Aksum and Himyar', HTS Teologiese Studies/Theological Studies 76(1), a5908. https://doi.org/10.4102/hts.v76i1.5908

Rukuni, R. \& Oliver, E., 2020, Religious statecraft: Narratives of persecution and diplomacy the case of Byzantine, Aksum and Himyar, HTS, Capetown.

Schaff, P. (ed.), 1885a, 'Ante-nicene fathers', vol. 3: Latin Christianity: Its founder, Tertullian, Christian Classics Ethereal Library, Grand Rapids, MI.

Schaff, P. (ed.), 1885b, 'Nicene and post-nicene fathers', Series 2, vol. 1: Eusebius Pamphilius: Church history, life of Constantine, oration in praise of Constantine, Christian Classics Ethereal Library, Grand Rapids, MI.
Schaff, P. (ed.), 1885c, 'Nicene and post-nicene fathers', Series 2, vol. 2: Socrates and Sozomenus Ecclesiastical histories, Christian Classics Ethereal Library, Grand Rapids, MI.

Shahid, I., 1976, The Kebra Naghast in the light of recent research, Le Museon, 89 (1976), pp. 133-178, Editions Peeters, Louvain republished in A. Bausi (ed.), 2012, Languages and cultures of Eastern Christianity: Ethiopian, pp. 253-298, Ashgate Publishing Ltd, Surrey.

Silverman, A., 2005, Painting Ethiopia: The life and work of Qes Adamu Tesfaw, UCLA Fowler Museum of Cultural History, LA.

Sima, A., 2007, 'Entry under “Mahrem”', Uhlig 3, 661-662.

Smith, K., 2016, Constantine and the captive Christians of Persia: Martyrdom and religious identity in late antiquity, University of California Press, CA.

Spiegel, S., 1958, Amos versus Amaziah, Herbert H. Lehman Institute of Ethics, New York, NY.

Stemberger, G., 1999, 'Jerusalem in the early seventh century: Hopes and aspirations of Christians and Jews', in L.I. Levine (ed.), Jerusalem its sanctity and centrality, to Judaism, Christianity, and Islam, pp. 260-271, The Continuum Publishing Company, New York, NY.

Stoyanov, Y., 2014, 'Apocalypticizing warfare: From political theology to imperial eschatology in seventh- to early eighth-century Byzantium', in K.B. Bardakjian \& S. La Porta (eds.), The Armenian apocalyptic tradition: A comparative perspective essays presented in honor of Professor Robert W. Thomson on the occasion of his eightieth birthday, pp. 379-433, Brill, Leiden.

Tabaar, M.A., 2018, Religious statecraft: The politics of Islam in Iran: Columbia studies in Middle East politics, Columbia University Press, New York, NY.

Tamrat, T., 1972, Church and state in Ethiopia: 1270-1527, Clarendon Press, Oxford.

The Holy Bible: King James Version, 2009, Electronic edition of the 1900 authorized version, Logos Research Systems, Inc, Bellingham, WA.

Trimingham, J.S., 1965, Islam in Ethiopia, Frank Cass and Co., Ltd., London, viewed 15 November 2019, from https://hadithcollection.com/sahihbukhari.html.

Webster, A.F.C., 1980, 'Varieties of Christian military saints: From martyrs under Caesar to warrior princes', SVTQ 24, 3-35.

Wilhite, D.E., 2017, Ancient African Christianity: An introduction to a unique context and tradition, Routledge, New York, NY.

Wittgenstein, L., 1958, Philosophical investigations, vol. 1, nos. 242-246, transl. G.E.M. Anscombe, Macmillan, New York, NY.

Yotam, H., 2008, 'Nationalized Judaism and diasporic existence. Jakob Klatzkin and Hans Jonas', Behemoth. A Journal on Civilisation 1(2), 67-78. https://doi. org/10.1524/behe.2008.0016 